\title{
Epiphytic bryophytes of the State Dendrological Park "Olexandria" of the NAS of Ukraine
}

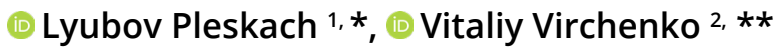 \\ 1 State Dendrological Park "Olexandria", National Academy of Sciences of Ukraine, 09113 Bila Tserkva, Ukraine; \\ * I.pleskach@ukr.net \\ ${ }^{2}$ M.G. Kholodny Institute of Botany, National Academy of Sciences of Ukraine, Tereshchenkivska str. 2, 01601 Kyiv, Ukraine; \\ ** vir_chen_ko@ukr.net
}

Received: 29.10.2020 | Accepted: 28.11.2020 | Published: 30.12 .2020

\begin{abstract}
Investigations of the species diversity of epiphytic bryophytes of the State Dendrological Park "Olexandria" (the historical part and the "Budynok Lisnyka" plot) were conducted in 2017-2019 and revealed 40 species representing 22 genera, 17 families, seven orders, two classes, and two divisions. This corresponds to $46.51 \%$ of the total number of detected bryophytes in the park. The leading families in the bryoflora of the park are Orthotrichaceae (9 species), Brachytheciaceae (6), Amblystegiaceae (3), Anomodontaceae (3), Dicranaceae (3), Hypnaceae (3), and Pottiaceae (2). The leading genera are Orthotrichum (9 species), Anomodon (3), and Dicranum (3).

Among the identified taxa, five species (Dicranum tauricum, Orthotrichum lyellii, Porella platyphylla, Sciuro-hypnum reflexum, and Syntrichia virescens) are regionally rare within the Forest-Steppe zone of Ukraine. Most of the recorded epiphytic mosses were found on the bark of Acer platanoides (28 species), Fraxinus excelsior (27), Quercus robur (26), Acer campestre (23), and Tilia cordata (22). The least epiphytic mosses were found on the bark of conifers (Pinus sylvestris, P. strobus, Picea abies, Larix decidua, etc.).

The surveyed trees in the State Dendrological Park "Olexandria" were also found such epigeal mosses as Plagiomnium cuspidatum, Ceratodon purpureus, Dicranella heteromalla, and Pohlia nutans, as well as epixilic moss Dicranum flagellare, etc.

The "Budynok Lisnyka" plot hosts three species that do not occur in the park's historical part. In particular, Lophocolea heterophylla and Sciuro-hypnum curtum were found there on Quercus robur trunks and Sciuro-hypnum reflexum on Quercus rubra bark. At the same time, the historical part of the park is characterized by the number of expansive bryophytes.
\end{abstract}

Keywords: epiphytic bryophytes, taxonomic diversity, State Dendrological Park "Olexandria"

\section{Introduction}

Biodiversity conservation is one of the essential tasks to be completed, mainly through the nature conservation areas. One of such areas is the State Dendrological Park "Olexandria" of the NAS of Ukraine, established in 1788. At present, there are registered over 3100 species of arboreal plants and over 1500 herbs. However, the diversity of bryophytes of the park is still insufficiently investigated. Hence, our research's objective was to reveal the taxonomic diversity of epiphytic bryophytes in this park. 


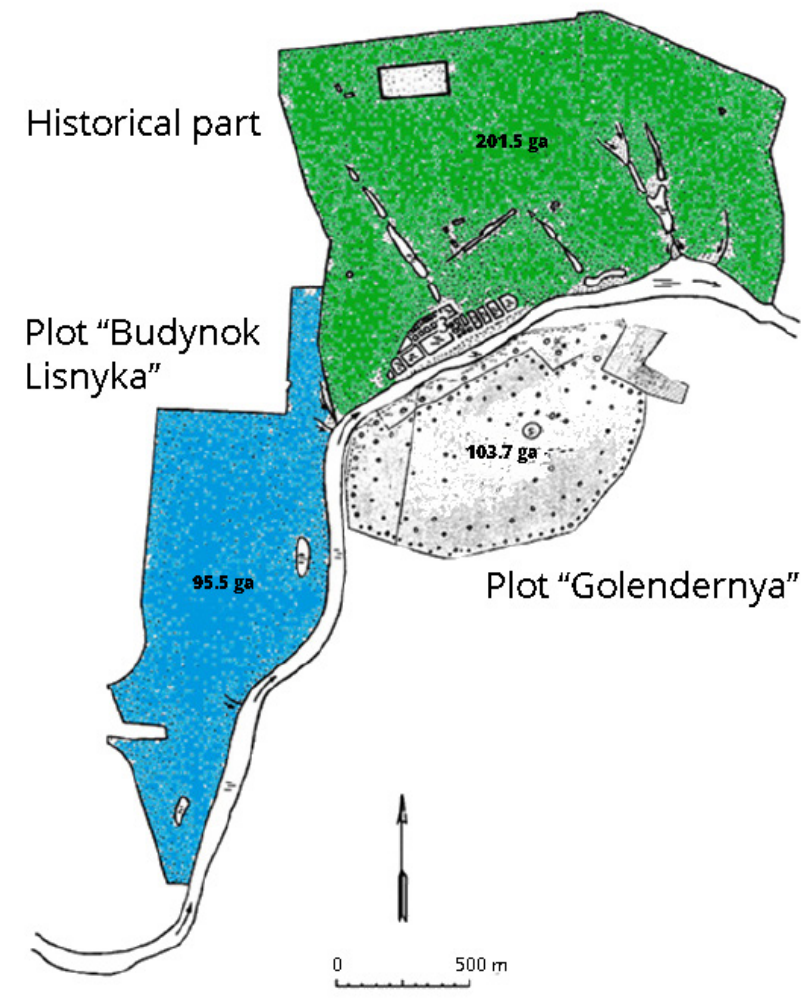

Figure 1. Scheme of the State Dendrological Park "Olexandria".

\section{Material and methods}

Investigations were carried out in 2017-2019 in the historical part and the "Budynok Lisnyka" plot of the State Dendrological Park "Olexandria" of the NAS of Ukraine (Fig. 1). The species diversity of epiphytic mosses was studied predominantly on the following phorophytes: Quercus robur L., Acer campestre L., A. platanoides L., A. pseudoplatanus L., Tilia cordata Mill., Fraxinus excelsior L., Betula pendula Roth., Carpinus betulus L., Aesculus hippocastanum L., Picea abies (L.) Karst., and Populus alba L. The names of taxa are provided according to Boiko (2008a, 2014), and their taxonomic position is given following Boiko (2008b). Phorophytes were subdivided onto native and introduced basing on Didukh (2002a, 2002b, 2005).

\section{Results and discussion}

Our research results showed that the epiphytic bryoflora of the State Dendrological Park "Olexandria" comprises 40 species belonging to 22 genera, 17 families, seven orders, two classes, and two divisions (Table 1).
At present, the bryoflora of the State Dendrological Park "Olexandria" includes 98 species. Hence, the 40 mentioned epiphytic taxa represent $40.8 \%$ of the total bryodiversity of the park. Most of the investigated epiphytic taxa (36 species or $90 \%)$ belong to the class Bryopsida from the division Bryophyta. The leading families are Orthotrichaceae (9 species), Brachytheciaceae (6), Amblystegiaceae (3), Anomodontaceae (3), Dicranaceae (3), Hypnaceae (3), and Pottiaceae (2). These families comprise 29 species and represent $70 \%$ of the total number of explored epiphytic bryophytes. The leading genera are Orthotrichum (9 species), Anomodon (3), Dicranum (3), and Sciurohypnum (3). The division Marchantiophyta is represented only by four species from the class Jungermanniopsida, which corresponds to $10 \%$ of the total number of explored taxa.

Among the identified taxa, five species (Dicranum tauricum, Orthotrichum lyellii, Porella platyphylla, Sciuro-hypnum reflexum, and Syntrichia virescens) are regionally rare within the Forest-Steppe zone of Ukraine (Boiko, 2010).

Bryophytes, which occur on the bark, are not an ecologically homogeneous group. In addition to the true epiphytes, limited by the bark of living trees, on the trunks and roots of phorophytes settle many species with a broader ecological amplitude (Rykovsky, 1989). Thus, on the surveyed trees in the State Dendrological Park "Olexandria" such epigeal mosses as Plagiomnium cuspidatum (Hedw.) T.J. Kop., Ceratodon purpureus (Hedw.) Brid., Dicranella heteromalla (Hedw.) Schimp., and Pohlia nutans (Hedw.) Lindb., as well as epixilic moss Dicranum flagellare Hedw. and some others were also discovered.

The historical part of the State Dendrological Park "Olexandria" counts 37 epiphytic bryophytes and the "Budynok Lisnyka" plot - 23 taxa. In the "Budynok Lisnyka" plot, there are unique species that do not occur in the historic part of the park. In particular, Lophocolea heterophylla and Sciuro-hypnum curtum were found there on Quercus robur trunks and S. reflexum on Quercus rubra $\mathrm{L}$. bark. At the same time, the historical part of the park hosts many expansive bryophytes.

The largest number of epiphytic bryophytes was recorded on the bark of Acer platanoides (28 species), Fraxinus excelsior (27), Quercus robur 
Table 1. Taxonomic structure of epiphytic bryoflora of the State Dendrological Park "Olexandria".
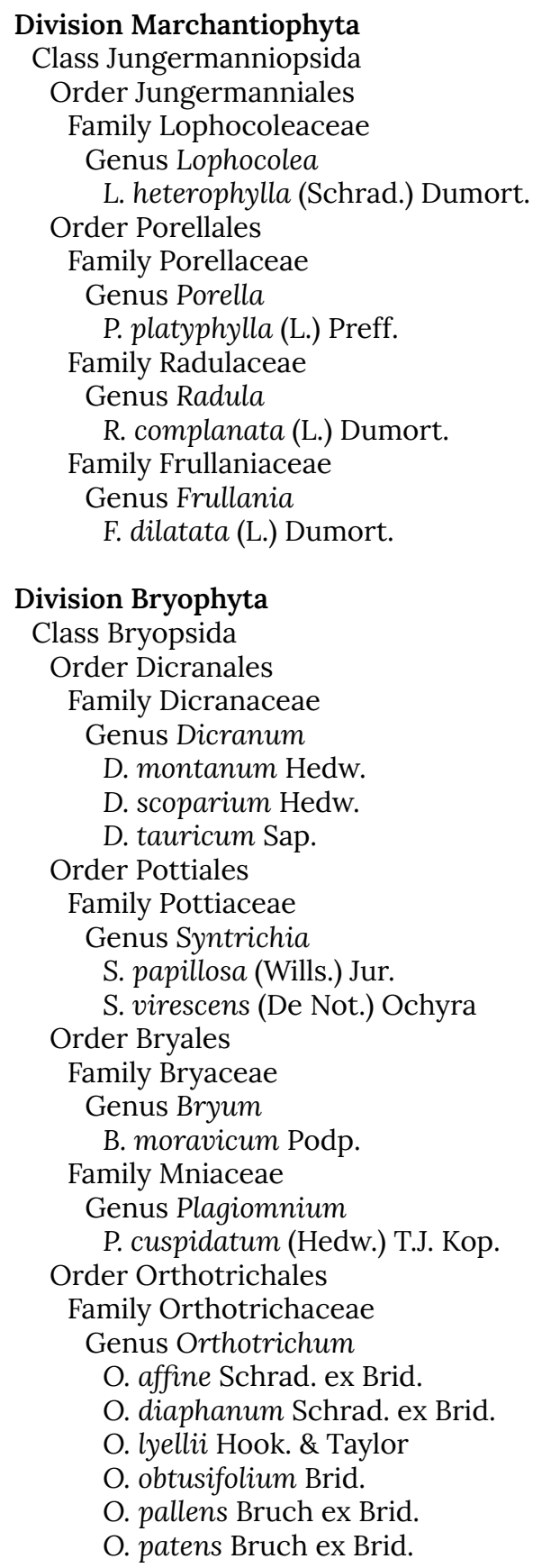

(26), Acer campestre (23), and Tilia cordata (22) (Fig. 2). Slightly fewer species were found on Betula pendula (16 species), Carpinus betulus (16), Populus alba (11), P. × canescens (Ait.) Smith (10), Pyrus communis Mill. (10), Populus tremula L. (9), and Alnus glutinosa (L.) Gaerth. (7). Hence, Acer platanoides, Fraxinus excelsior, and Quercus robur were characterized by the richest epiphytic bryoflora. Acer platanoides hosted $72.5 \%$, Fraxinus excelsior $-67.5 \%$, and Quercus robur - $62.5 \%$ of epiphytic bryophytes of the State Dendrological Park "Olexandria".

The most common mosses on the bark of Tilia cordata were Hypnum cupressiforme,

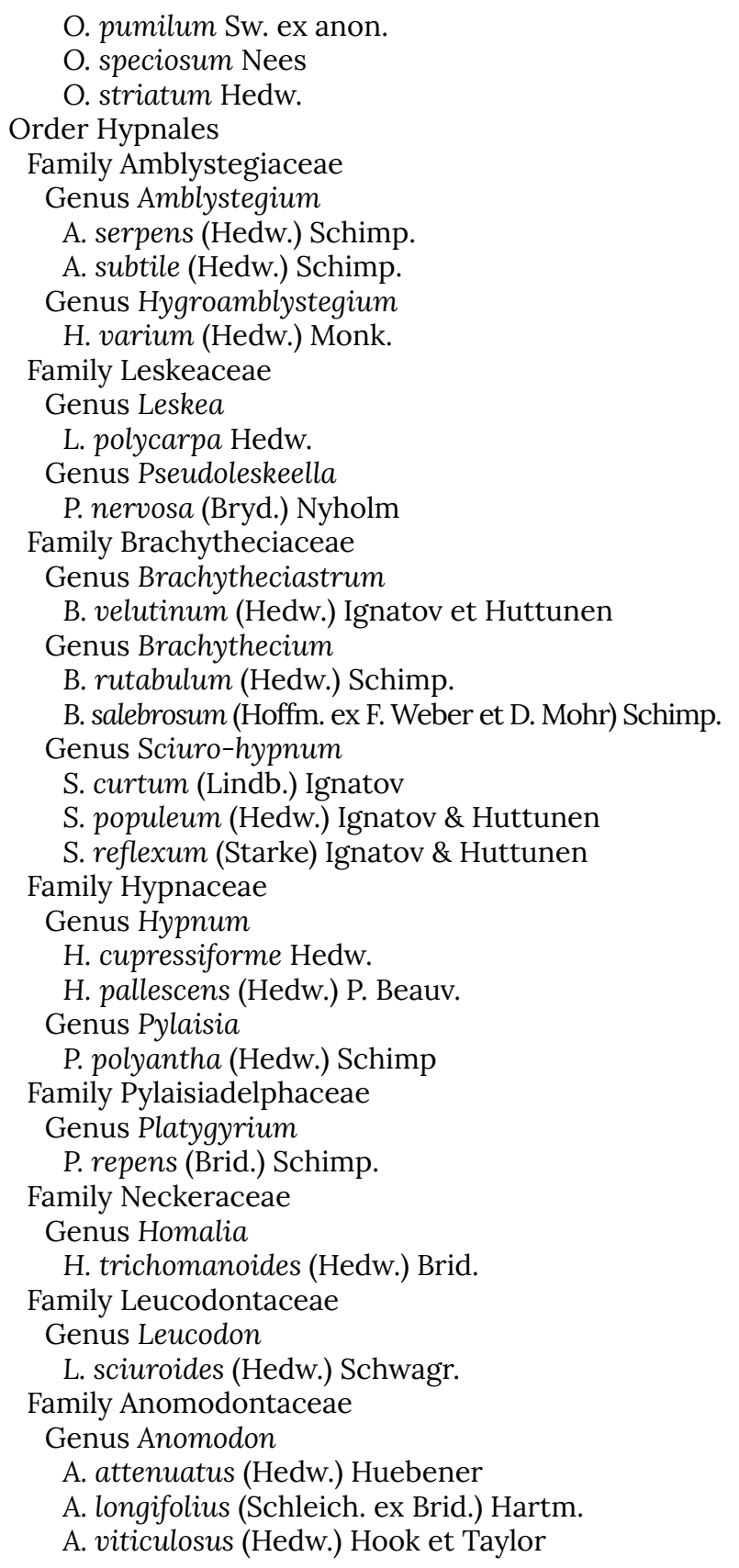

Pseudoleskeella nervosa, Platygyrium repens, Leskea polycarpa, and Leucodon sciuroides; on the bark of Acer platanoides - Leskea polycarpa, Pseudoleskeella nervosa, Orthotrichum speciosum, Hypnum cupressiforme, and Leucodon sciuroides; on the bark of Fraxinus excelsior - Leskea polycarpa, Orthotrichum speciosum, Leucodon sciuroides, Hypnum cupressiforme, Pseudoleskeella nervosa, and Pylaisia polyantha; on the bark of Quercus robur Hypnum cupressiforme, Platygyrium repens, Bryum moravicum, and Pseudoleskeella nervosa (Fig. 3). 


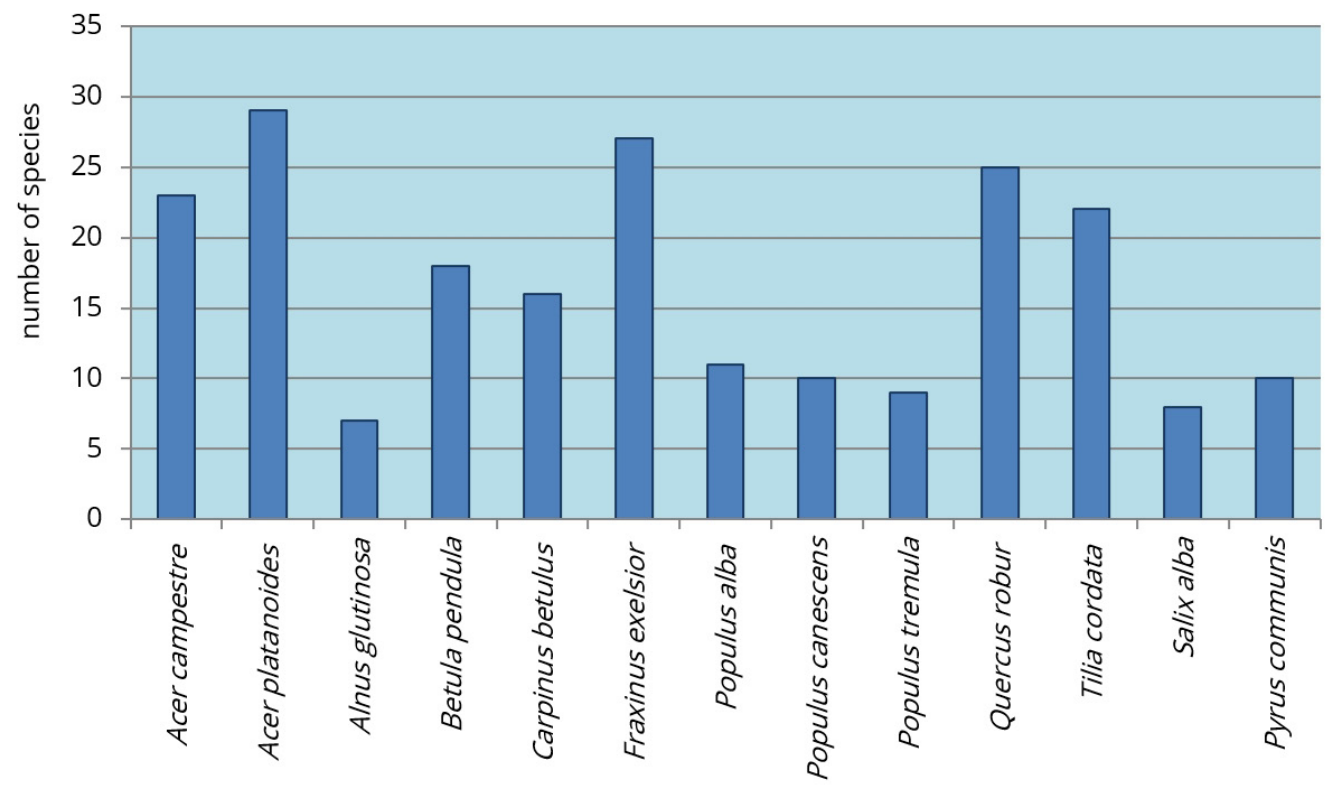

Figure 2. Species richness of epiphytic bryophytes distributed on the main park-forming and some other tree species of the State Dendrological Park "Olexandria".

Such species as Brachythecium salebrosum, Brachytheciastrum velutinum, Bryum moravicum, Hypnum cupressiforme, Leskea polycarpa, Leucodon sciuroides, Orthotrichum patens, O. pumilum, O. speciosum, Platygyrium repens, Porella platyphylla, Pseudoleskeella nervosa, and Pylaisia polyantha we have recorded on the bark of most arboreal plants (Fig. 3). However, some bryophytes occurred exclusively on certain tree species. For example, Dicranum scoparium and D. tauricum were found only on the bark of Betula pendula; Brachythecium rutabulum - exclusively on the bark of Acer platanoides; Frullania dilatata, Sciuro-hypnum curtum, and Lophocolea heterophylla - on the bark of Quercus robur; Sciuro-hypnum reflexum - on the bark Quercus rubra; Orthotrichum striatum - on the trunk of Fraxinus excelsior.

The richness of bryophytes on introduced trees was lower than on the native arboreal species. Thus, Acer pseudoplatanus hosted only 15 species of epiphytic bryophytes, while A. platanoides - 28 species, and A. campestre - 23 species. Quercus rubra hosted 11 species, while Q. robur 26 species. On the bark of Robinia pseudoacacia we have found 13 species of bryophytes, on Aesculus hippocastanum - 11 species, and on Catalpa ovata G. Don. - eight species (Fig. 4). On the trunks of such broad-leaved species as Platanus $\times$ acerifolia (Ait.) Willd. and Juglans cinerea L. we have found only five species of bryophytes per each tree species, on Cercidiphyllum japonicum Sieb. et Zucc. and Juglans nigra L. - four species, on Celtis mississipiensis Bosc. and Gleditsia triacanthos L. - three species. Lower species diversity of mosses on some introduced plants is probably related to their bark properties and the conditions of growing. In the State Dendrological Park "Olexandria" they were mostly planted as solitary trees or in small curtains on the lawns. Hence, such plants grow in good light, which, however, results in conditions that are not optimal for the development of most mosses.

Nevertheless, the smallest number of epiphytes occurred on the bark of conifers. Thus, on the bark of Pinus sylvestris L. we recorded only four species of mosses, on the bark of Pinus strobus L., Picea abies (L.) Karst., Larix decidua Mill. and some others - only two species. This is because their bark, unlike most deciduous trees, has higher acidity (Insarova \& Insarov, 1989). Moreover, conifers constantly shed their bark, which explains the absence or a low number of hosted bryophytes (Sluka, 1975; Dymytrova, 2008).

\section{Conclusions}

Our study showed that epiphytic bryoflora of the State Dendrological Park "Olexandria" includes 40 species, which corresponds to 

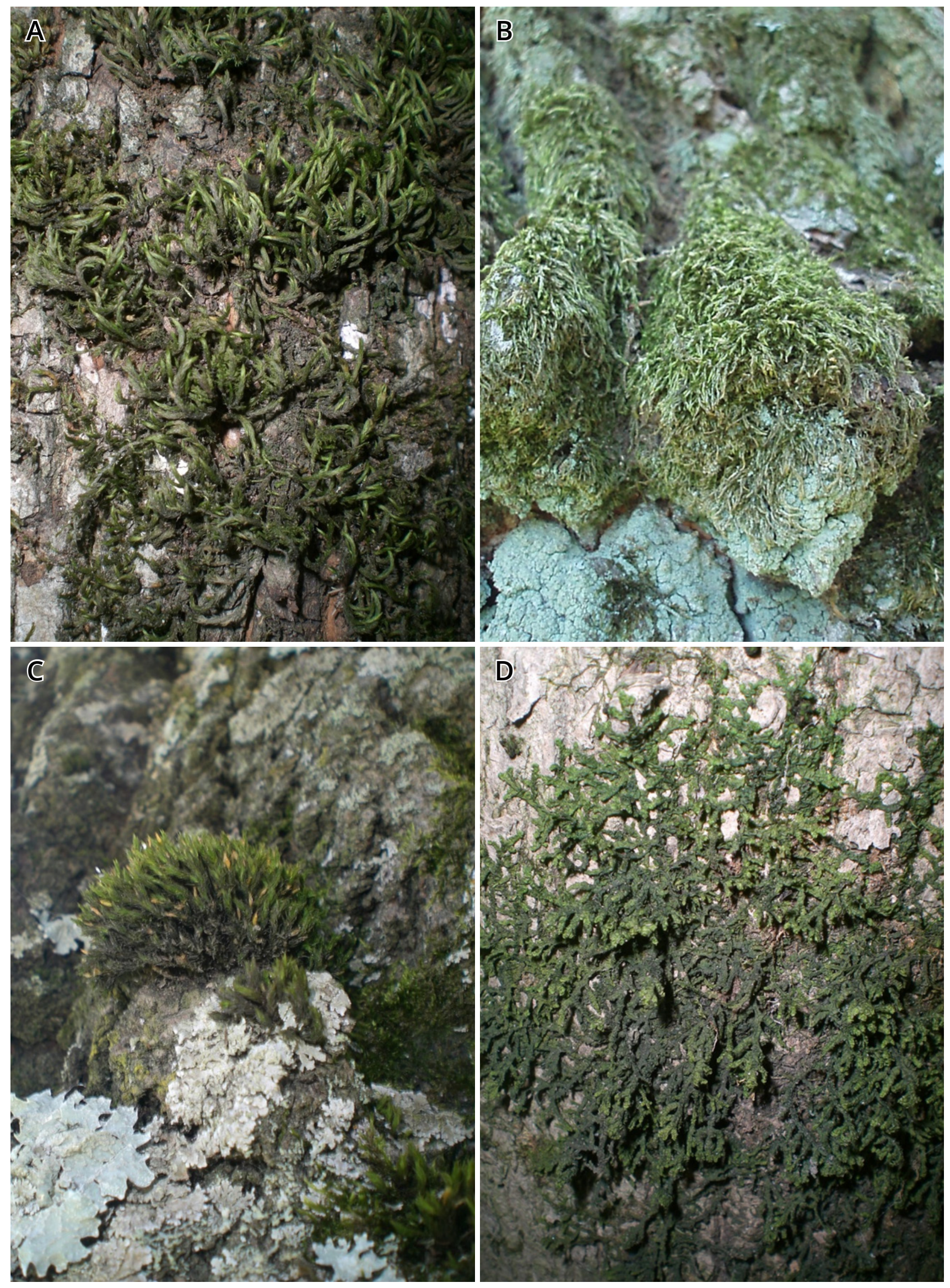

Figure 3. Leucodon sciuroides on the bark of Fraxinus excelsior (A) and Hypnum cupressiforme on the bark of Quercus robur (B); Orthotrichum speciosum on the bark of Populus $\times$ canescens (C); Porella platyphylla on the bark of Acer campestre (D). 


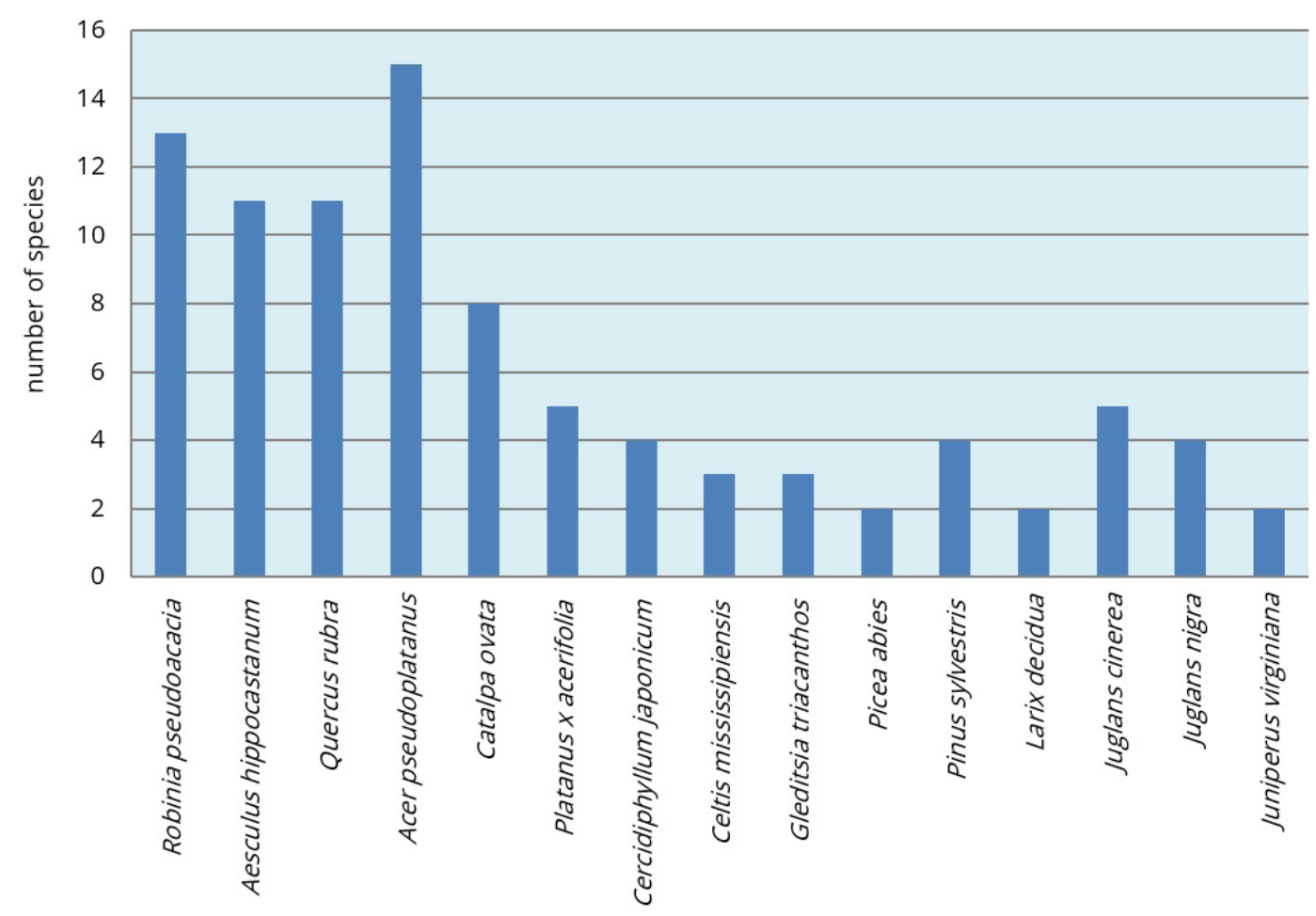

Figure 4. Species richness of epiphytic bryophytes distributed on some exotic tree species of the State Dendrological Park "Olexandria".

$46.51 \%$ of the total number of bryophytes detected in the park. It includes five species (Dicranum tauricum, Orthotrichum lyellii, Porella platyphylla, Sciuro-hypnum reflexum, and Syntrichia virescens), which are regionally rare within the Forest-Steppe zone of Ukraine.

The largest number of epiphytic bryophytes species was recorded on the bark of such native trees as Acer platanoides, A. campestre, Fraxinus excelsior, Quercus robur, and Tilia cordata. Introduced plants hosted a relatively small number of bryophytes. The smallest number of epiphytic bryophytes was found on the bark of conifers Pinus sylvestris, P. strobus, Picea abies, Larix decidua, and some other species.

Such epiphytic bryophytes as Brachythecium salebrosum, Brachytheciastrum velutinum, Bryum moravicum, Hypnum cupressiforme, Leskea polycarpa, Leucodon sciuroides, Orthotrichum patens, O. pumilum, O. speciosum, Platygyrium repens, Porella platyphylla, Pseudoleskeella nervosa, and Pylaisia polyantha were recorded on the bark of most of the studied tree species.

\section{References}

Boiko, M. F. (2008a). A checklist of the bryobionta of Ukraine. Kherson: Ailant. (In Ukrainian)

Boiko, M. F. (2008b). A checklist of bryobionta of Ukraine (taxanomical review, overspecies taxons). Chornomorski Botanical Journal, 4(2), 151160. (In Ukrainian)

Boiko, M. F. (2010). Red list of bryobionta of Ukraine. Rare and endangered species of the bryobionta of Ukraine. Kherson: Ailant. (In Ukrainian)

Boiko, M. F. (2014). The second checklist of bryobionta of Ukraine. Chornomorski Botanical Journal, 10(4), 427-487. (In Ukrainian)

Didukh, Y. P. (Ed.). (2002a). Dendroflora of Ukraine. Wild and cultivated trees and shrubs. Gymnosperms. Kyiv: Phytosociocenter. (In Ukrainian)

Didukh, Y. P. (Ed.). (2002b). Dendroflora of Ukraine. Wild and cultivated trees and shrubs. Angiosperms. Part 1. Kyiv: Phytosociocenter. (In Ukrainian)

Didukh, Y. P. (Ed.). (2005). Dendroflora of Ukraine. Wild and cultivated trees and bushes. Angiosperms. Part 2. Kyiv: Phytosociocenter. (In Ukrainian)

Dymytrova, L. V. (2008). Epiphytic lichens and bryophytes distribution on wood species in Kyiv city. Proceedings of V.N. Karazin Kharkiv National University. Series Biology, 7(814), 30-37. (In Ukrainian) 
Insarova, I. D., \& Insarov G. E. (1989). Comparative assessment of the sensitivity of epiphytic lichens of different species to air pollution. Problems of Ecological Monitoring and Modeling of Ecosystems, 12, 113-175. (In Russian)

Rykovsky, G. F. (1989). Epiphytic mosses as an ecological group of extreme habitats. In I. I. Abramov (Ed.), Problems of bryology in the USSR (pp. 190-201). Leningrad: Nauka. (In Russian)
Sluka, Z. A. (1975). On the regularities of the growth of epiphytic mosses. Proceedings of the Moscow University. Biological and Soil Sciences, 5, 43-49. (In Russian)

\section{Епіфітні бріофіти Державного дендрологічного парку “Олександрія" НАН України}

Любов Плескач 1, *, Віталій Вірченко 2, **

1 Державний дендрологічний парк “Олександрія” НАН України, Біла Церква, 09113, Україна; * I.pleskach@ukr.net

2 Інститут ботаніки ім. М.Г. Холодного НАН України, вул. Терещенківська, 2, Київ, 01004, Україна; ** vir_chen_ko@ukr.net

Дослідження дендропарку “Олександрія" (історичної частини та урочища "Будинок лісника"), виконані у 2017-2019 роках дали змогу виявити 40 видів епіфітних мохоподібних, що представляють 22 роди, 17 родин, сім порядків, два класи та два відділи. Це відповідає 46,51\% від загального числа виявлених бріофітів парку. Провідними родинами $\epsilon$ Orthotrichaceae (9 видів), Brachytheciaceae (6), Amblystegiaceae (3), Anomodontaceae (3), Dicranaceae (3), Hypnaceae (3) та Pottiaceae (2). Провідними родами - Orthotrichum (9 видів), Anomodon (3) та Dicranum (3).

Серед виявлених видів п'ять (Dicranum tauricum, Orthotrichum Iyellii, Porella platyphylla, Sciuro-hypnum reflexum та Syntrichia virescens) $\epsilon$ регіонально рідкісними в межах лісостепової зони України. Більшість епіфітних мохоподібних було виявлено на корі Acer platanoides (28 видів), Fraxinus excelsior (27), Quercus robur (26), Acer campestre (23) і Tilia cordata (22). А найменше видове різноманіття епіфітних мохоподібних було на корі хвойних (Pinus sylvestris, P. strobus, Picea abies, Larix decidua тощо).

Окрім того, у дендропарку “Олександрія" на обстежених деревах було виявлено епігейні види Plagiomnium cuspidatum, Ceratodon purpureus, Dicranella heteromalla та Pohlia nutans, а також епіксильні мохи Dicranum flagellare та ін.

В урочищі “Будинок лісника" виявлено три види мохоподібних, які не трапляються в історичній частині парку. Зокрема, Lophocolea heterophylla та Sciuro-hypnum curtum було виявлено на стовбурах Quercus robur, a Sciuro-hypnum reflexum - на корі Quercus rubra. Водночас з'ясовано, що історична частина парку відрізняється присутністю значного числа експансивних видів бріофітів. 